\title{
THE EFFECT OF AGRICULTURAL EXTENSION SERVICE ON THE TECHNICAL EFFICIENCY OF TEFF (ERAGROSTISTEF) PRODUCERS IN ETHIOPIA
}

\author{
${ }^{1}$ Asres Elias, ${ }^{2}$ Makoto Nohmi, ${ }^{2}$ Kumi Yasunobu, ${ }^{3}$ Akira Ishida and ${ }^{4}$ Arega D. Alene \\ ${ }^{1}$ The United Graduate School of Agricultural Sciences, Tottori University, Japan \\ ${ }^{2}$ Faculty of Agriculture, Tottori University, Japan \\ ${ }^{3}$ Faculty of Life and Environmental Science, Shimane University, Japan \\ ${ }^{4}$ International Institute of Tropical Agriculture (IITA), Lilongwe, Malawi
}

Received 2013-10-30; Revised 2013-12-18; Accepted 2013-12-21

\begin{abstract}
Teff (Eragrostistef) is a major staple food crop in Ethiopia, but smallholder teff production is characterized by persistently low average yield. A major government effort aimed at raising the productivity and competitiveness of smallholder agriculture in Ethiopia involved reforming and implementing agricultural extension service known as Participatory Demonstration and Training Extension System (PADETES). Therefore, this study investigates the effect of agricultural extension service and other factors on the Technical Efficiency (TE) of teff producers in northern Ethiopia. Using cross sectional data we compare TE level of teff producers who are participants and non-participants of Agricultural Extension (AE) program. We address self-selection in to AE program participation using propensity score matching method. Trans$\log$ stochastic frontier production function is used for TE analysis. The empirical results reveal that, AE program participants' and non-participants' farms have an average TE of 72 and $71 \%$ respectively. Both groups of farms have considerable overall technical inefficiencies, suggesting the existence of immense potentials for enhancing production through more efficient use of available technology and resources. Determinants of TE are explained significantly by livestock ownership, credit and improved seed. Based on the results, we derive policy recommendations to improve farmers' teff production performance. These policy measures include the provision of extension services related to technical skill and farm management capacity of the farmers, demand driven livestock extension service, greater access to credit and increasing the availability, quality and adoption of improved seed.
\end{abstract}

Keywords: Agricultural Extension, Ethiopia, Propensity Score Matching, Selection-Bias, Technical Efficiency, Teff

\section{INTRODUCTION}

Agriculture is the most important sector for sustaining growth and reducing poverty in Ethiopia. It accounts for $85 \%$ of employment, $50 \%$ of exports and $43 \%$ of Gross Domestic Product (GDP) (FAO, 2010). In spite of its huge economic contribution, the sector is almost entirely dominated by subsistence, small-scale and resource poor farmers. More over lack of adequate farm management practices, low level of modern inputs usage, the depletion of soil organic matter, rain fed dependent agriculture system are major obstacles to sustain agricultural production in the country (Pender and Gebremedhin, 2007; Kassie et al., 2009).

In cognizant of these problems, the government of Ethiopia launched a strategy which is known as the Agricultural Development Led Industrialization (ADLI) in 1993 that sets out agriculture as a primary stimulus to

Corresponding Author: Asres Elias, The United Graduate School of Agricultural Sciences, Tottori University, Japan Tel: +81-80-4550-5224 
generate increased output, employment and income for the people and as the spring board for the development of the other sectors of the economy (Kassa and Abebaw, 2004; Gebremedhin et al., 2009). Following ADLI, one of the major programs formulated by the Ethiopian government is the national extension package program known as Participatory Demonstration and Training Extension System (PADETES). The objective of PADETES is to achieve sustainable development in rural areas through increasing farm productivity (yield), reducing poverty, increasing the level of food security, increasing the volume and variety of industrial raw materials (primary products) and producing for the export market (Kassa, 2003; EEA/EEPRI, 2006). The PADETES program has been intended to focus on supply-driven intensification which consists of promotion of improved seeds, fertilizers and on-farm demonstrations of improved farm practices (Kassa, 2008; Gebremedhin et al., 2009; Asfaw et al., 2012).

However, the performance of the agriculture sector has been very dismal in spite of implementing the national extension package program-PADETES. The country is still vulnerable to recurrent food shortfalls and national food insecurity (Abate et al., 2011). Despite considerable technological changes, agricultural production under improved technology in developing countries including Ethiopia encounters substantial inefficiencies due to farmers' high degree of unfamiliarity with new technology coupled with poor extension, education, credit and input supply system among others (Alene and Zeller, 2005). Since the introduction of new technologies requires intensive management and information, farmers in developing countries with low literacy rates, poor extension services and inadequate physical infrastructures have great difficulty in adopting new technologies, let alone exploiting their full potentials (Alene and Hassan, 2006).

Technical Efficiency (TE) is the extent to which the maximum possible output is achieved from a given combination of available inputs. Any deviation from the maximal output is typically considered as technical inefficiency (Coelli et al., 2005). Hence, the presence of shortfalls in efficiency means that output can be increased without requiring additional conventional inputs and need for new technologies (Binam et al., 2004). If this is the case, then empirical measures of efficiency are necessary in order to determine the magnitude of the gain that could be obtained by improving performance in production with available resources.

In Ethiopia, as stated above measures have been taken to achieve high rate of adoption of new technologies, while little or no attention has been given to the question of whether there is appropriate application and efficient use of available resources and technologies. Hence, the measurement of $\mathrm{TE}$ has relevance for policy intervention, especially, in countries, like Ethiopia, where resources are meager and opportunities for developing and adopting better technologies are scarce. Moreover, studies that are systematically measuring TE of farmers who are participants and non-participants of Agricultural Extension (AE) program are scanty. Previous studies by (Seyoum et al., 1998; Khairo and Battese, 2005; Ayele et al., 2006; Alene and Hassan, 2008; Thangata and Mequaninte, 2011) are done without accounting for selection bias in agricultural extension participation. This study makes an attempt to go one step further and compare the difference in technical efficiency between the two groups that are similar in their observable covariates. Therefore, the objective of this study is to measure the effects of extension services and other factors on technical efficiency of teff producers in 3 selected kebeles (peasant associations) of Northern Ethiopia. The rest of this study is organized as follows. The next section presents motivation of efficiency analysis in teff production. The methodological framework is presented in the third section and the fourth section discusses the data and empirical procedures. The empirical results are presented in the fifth section and the last section draws conclusions and implications.

\subsection{Motivation for Efficiency Analysis of Teff Production in Ethiopia}

Teff, (Eragrostistef) is the main Ethiopian cereal crop annually grown on 2.5 million ha and accounts for $30 \%$ of total acreage and $19 \%$ of gross cereal production (CSA, 2008). The crop has both its origin and diversity in Ethiopia and plays a vital role in the country's overall food security. The straw is an important cattle feed source and the high market prices of both its grains and the straw make it a highly valued cash crop for teff growing smallholder farmers. Teff is a highly versatile crop with respect to adaptation to different agroecologies, with reasonable resilience to both drought and waterlogging (Assefa et al., 2011a). Scientific research on teff began in the late 1950s and over the years a number of improved varieties and management practices have been developed. Now a days it is one of the major cereal crops which is promoted by the agricultural extension program in Ethiopia. It has its own recommended rates of chemical fertilizer, seed and management practices (such as plouing frequency, weed control, post-harvest activities among others). However, there is little adoption rate by farmers and have brought 
few impact on teff production (Assefa et al., 2011b). In addition, despite teff's great significance to Ethiopians, its average yield has remained low (1.3 t/ha) and supply has not kept pace with demand. Furthermore, growth in teff production has mainly come from expanding the amount of land under cultivation ATA (2012), which is a limited resource in Ethiopia. Therefore, teff production growth through land expansion would not be sustainable. Moreover, past studies on TE in Ethiopia were limited to very few crops; it even did not take into account teff crop. Therefore, it's important to study technical efficiency level of teff producers to understand by how much production can be grown through efficient utilization of available technology and resources.

\section{MATERIALS AND METHODS}

According to the neo-classical definition of technical efficiency, a production process is technically efficient if and only if it yields the maximum possible output from a given combination of inputs. TE can be measured by using input or output-oriented approaches. The inputoriented approach addresses the question "by how much can input quantities be proportionally reduced without changing the output quantities produced?" The outputoriented approach (which is the focus of this study, given we are considering developing country settings, the concern is rather not inputs are over-used but output short-fall) addresses the question "by how much can output be increased without increasing the amount of input use by utilizing the given inputs more efficiently?" (Coelli et al., 2005).

Frontier techniques have been widely used in determining the farm-level efficiency in developing countries' agriculture since the publication of a seminal article of Farrell (1957) on efficiency measurement and subsequent development of several approaches to efficiency and productivity measurement. Among the different approaches followed to measure efficiency, the Stochastic Frontier Production Function (SFPF) approach involving econometric estimation of parametric function (Aigner et al., 1977; Meeusen and den Broeck, 1977) and nonparametric programming, known as Data Envelopment Analysis (DEA), are the most popular. The stochastic frontier is considered more appropriate for assessing TE in developing countries' agriculture, where the data are often heavily influenced by measurement errors and other stochastic factors such as weather condition and others (Coelli et al., 2005; Dey et al., 2005).

There are two approaches to analyze determinants of technical efficiency. Several efficiency measurement studies (Bravo-Ureta and Pinheiro, 1997; Nyemeck et al., 2003; Nkamleu, 2004) have first estimated stochastic frontiers to predict firm-level efficiencies and then regress these predicted efficiencies upon farm-specific variables in an attempt to explain variations in output between firms in an industry. This is usually referred as a two-stage procedure. However, several economists have criticized the two stage procedure (Battese et al., 1989; Reifschneider and Stevenson, 1991; Battese and Coelli, 1995) arguing that the socio-economic variables should be incorporated directly in to the estimation of production frontier model because such variables may have a direct influence on the production efficiency. To overcome inconsistencies in the assumptions regarding the independence of inefficiency effects (Battese and Coelli, 1995; Coelli, 1996) extended the stochastic production frontier model by suggesting that inefficiency effects $\left(\mathrm{u}_{\mathrm{i}}\right)$ are expressed as an explicit function of a vector of farm specific variables and a random error. The (Battese and Coelli, 1995) model allows estimation of the farm specific efficiency scores and the factors explaining efficiency variations among farmers in a single stage estimation procedure. This study applies this model.

\subsection{Stochastic Frontier Production Function}

The Stochastic frontier model was first proposed by (Aigner et al., 1977; Meeusen and den Broeck, 1977) independently to account for the presence of measurement errors and other noise in the data, which are beyond the control of firms. The model decomposes the error term into a two-sided random error that captures the random effects outside the control of the firm (the decision making unit) and the one-sided efficiency component.

The stochastic frontier production function model is given by:

$$
Y_{i}=f\left(x_{i} ; \beta\right) \exp \left(v_{i}-u_{i}\right)
$$

Where:

$\mathrm{Y}=$ The quantity of output on the ith firm

$\mathrm{x} \quad=\mathrm{A}$ vector of inputs used

$\beta=$ A vector of parameters

$\mathrm{f}\left(\mathrm{x}_{\mathrm{i}} ; \beta\right)=$ A suitable production function

$\mathrm{v}=\mathrm{A}$ random error term assumed to be independently and identically distributed as $\mathrm{N}\left(0, \sigma_{\mathrm{u}}^{2}\right)$, independent of $\mathrm{u}$ which represents technical inefficiency and is identically and independently distributed as truncated normal, with truncation at zero of the normal distribution (Battese and Coelli, 1995)

The maximum likelihood estimation of Equation (1) yields estimator for $\beta$ and $\gamma$, where $\gamma=\frac{\sigma_{u}^{2}}{\sigma^{2}}$ 
and $\sigma^{2}=\sigma_{u}^{2}+\sigma_{v}^{2}$. The total variation of output from the frontier, which is attributed to technical inefficiency, is given by $\gamma$ and has a value between zero and one.

Battese and Coelli (1995) proposed a model in which the technical inefficiency effects in a stochastic production frontier are a function of other explanatory variables. In their model, the technical inefficiency effects, $u$ are obtained by truncation (at zero) of the normal distribution with mean, $\mu_{\mathrm{i}}$ and variance $\sigma_{\mathrm{u}}^{2}$, such that Equation (2):

$$
\mu_{\mathrm{i}}-\mathrm{z}_{\mathrm{i}} \delta
$$

Where:

$\mathrm{z}_{\mathrm{i}} \quad \mathrm{A}$ vector of farm-specific explanatory variables and

$\delta=$ A vector of unknown coefficients of the farmspecific inefficiency variables

\subsection{Self-Selection in to Agricultural Extension Program Participation}

When estimating a production frontier the underlying assumption is that all farmers in the sample have access to the same production technology. But this study includes a sub-sample of farmers participating in $\mathrm{AE}$ program who have information access and technical support from extension workers. To account for differences in $\mathrm{AE}$ participation separate production frontiers are estimated for each sub-sample of farmers by previous studies (Seyoum et al., 1998; Alene and Hassan, 2006). These sub-samples, however, are unlikely to represent unbiased representations of the population. If farmers choose to participate in the AE program based on their expected performance, the two sub-samples will systematically differ with respect to certain farm and household characteristics. In particular, farmers who have better access to information and education may be more likely to participate in the program due to their ability to easily understand how to implement new technologies (Doss and Morris, 2000) or extension program might target farmers who are educated due to their capacity of investing in improved technologies through participation in the non-farm sector (Barrett et al., 2001; Cunguara and Moder, 2011). Similarly, farmers with larger land holdings and livestock ownership may be more likely to participate in the program as they may be better able to deal with the risks associated with the adoption of a new production technology. Furthermore, as the Ethiopian agriculture system is labour intensive, households with better availability of family labor may be more likely to participate in the program. In addition age can influence participation negatively or positively. Older farmers are often viewed as less flexible and less willing to engage in a new or innovative activity due to fear of risk whereas young farmers may be more risk averse to implement new technologies on their farm (Gebremedhin et al., 2009). Hence, the influence of age on participation decision is ambiguous.

In the study area, a hard-working and productive farmer is often described by the locals by how well he/she does the different farm activities starting from land preparation to post-harvest. The quality of doing these activities can better be estimated from the number of oxen days a farmer used at plot level, which was collected during our survey. Hence we used number of oxen days to characterize each farmer's commitment to farming and such kind of farmers might have high probability of participation in the extension program. Membership in cooperatives can also influence participation positively due to either extension workers might find it cheaper to target farmers group which helps them maximize the payoffs from efforts to build farmers capacity to demand advisory service (Benin et al., 2011; Cunguara and Moder, 2011) or membership in a social group provides opportunities to discuss and observe practices of other members at no cost or time intensity (Gebregziabher et al., 2011). Moreover, involvement in kebele administration could influence participation positively as follows: One kebele consists of four to seven villages. These villages are often relevant units for government initiatives and program. A village consists of limat budin, or development team for the implementation of a range of government activities, including mobilizing household labor for community projects. They also have political functions, such as mobilizing support and votes for the ruling party. Extension workers often work closely with limat budin (Cohen and Lemma, 2011; Birhanu, 2012). Hence, being in a position to involve in kebele administration with such kind of network system might increase the probability of participation in government sponsored extension program.

While these factors may influence the farmer's propensity to participate in the program and they are also likely to influence the farmer's production performance. Consequently, if selection bias is ignored in the estimation of separate production frontiers, coefficient estimates will be biased (Heckman et al., 1997). A common approach to address selection bias is the twostep Heckman procedure (Solis et al., 2007). However, this procedure is less suitable for nonlinear functions such as the stochastic frontier. We therefore use matching techniques similar to those of (Mayen et al., 
2010; Rao et al., 2012) to compare the TE of AE participant farms with similar non-participant farms. We employed a matching model known as Propensity Score Matching (PSM) (Smith and Todd, 2005; Caliendo and Kopeinig, 2008). This method compares the outcomes of program participants with those of matched nonparticipants, where matches are chosen on the basis of similarity in observed characteristics that eliminates selection bias (Heckman and Navarro-Lozano, 2004). Suppose there are two groups of farmers indexed by participation status $\mathrm{P}=0 / 1$, where 1 (0) indicates farms that did (not) participate in a program. Denote by $y_{i}^{1}$ the outcome (teff productivity) conditional on participation ( $\mathrm{P}=$ 1) and by $y_{i}^{0}$ the outcome conditional on non-participation $(\mathrm{P}=0)$. The most common evaluation parameter of interest is the mean impact of treatment on the treated:

$$
\mathrm{ATT}=\mathrm{E}\left(\mathrm{y}_{\mathrm{i}}^{1}-\mathrm{y}_{\mathrm{i}}^{0} \mid \mathrm{p}_{\mathrm{i}}=1\right)=\mathrm{E}\left(\mathrm{y}_{\mathrm{i}}^{1} \mid \mathrm{p}_{\mathrm{i}}=1\right)-\mathrm{E}\left(\mathrm{y}_{\mathrm{i}}^{0} \mid \mathrm{p}_{\mathrm{i}}=1\right)
$$

Which answers the question: 'How much did farms participating in the program benefit compared to what they would have experienced without participating in the program?' Data on $\mathrm{E}\left(\mathrm{y}_{\mathrm{i}}^{1} \mid \mathrm{p}_{\mathrm{i}}=1\right)$ are available from the program participants. The main problem is to find $\left(y_{i}^{0} \mid p_{i}=1\right)$, since data on non-participants enables one to identify $E\left(y_{i}^{0} \mid p=0\right)$ only. So the difference between $E\left(y_{i}^{1} \mid p=1\right)$ and $E\left(y_{i}^{0} \mid p=1\right)$ cannot be observed for the same farm. The solution advanced by Rubin (1977) is based on the assumption that given a set of observable covariates $\mathrm{X}$, potential (non-treatment) outcomes are independent of the participation status Conditional Independence Assumption (CIA): $\mathrm{y}_{\mathrm{i}}^{0} \perp \mathrm{S}_{\mathrm{i}} \mid \mathrm{X}$. Hence, after adjusting for observable differences, the mean of the potential outcome is the same for $\mathrm{P}=1$ and $\mathrm{P}=0$, $\left(E\left(y_{i}^{0} \mid p=1, X\right)=E\left(y_{i}^{0} \mid P=0, X\right)\right)$. This permits the use of matched non- participating farms to measure how the group of participating farms would have performed, if they had not participated. PSM is a two-step procedure. First, a probability model for AE participation is estimated and used to calculate the propensity score (pscore) for each observation using logit model. In the second step, each participant is matched to a nonparticipant with similar propensity score using different types of matching algorithms.

As explained above, the main assumption of PSM is selection on observables, also known as conditional independence or unconfoundedness assumption. Therefore, the specification of the propensity score is crucial because the logit model results depend on the unconfoundedness and overlap assumptions among others. Unconfoundedness assumption implies that adjusting for differences in observed covariates removes bias in comparisons between the two similar groups that only differs by AE participation. In other words, beyond the observed covariates, there are no unobserved characteristics that are associated both with the potential outcome and the treatment (Imbens and Wooldridge, 2009). Although unconfoundedness is formally untestable, there are ways to assess its plausibility. To address the unconfoundedness assumption different measures are taken by this study such as we included many covariates in our propensity score specification to minimize omitted variables bias following the suggestion in (Smith and Todd, 2005), then matching is implemented on the region of common support (Heckman et al., 1997). In addition, we employed a placebo regression (Imbens and Wooldridge, 2009) as a robustness check of the impact estimates to unobserved selection bias. This approach was used by (Abebaw and Haile, 2013; Cunguara and Moder, 2011) to test unobserved bias. The overlap assumption implies that the conditional distributions of the covariates of $\mathrm{AE}$ participants overlap completely with nonparticipants (Dehejia and Wahba, 2002; Imbens and Wooldridge, 2009). There are two formal methods of testing the overlap assumption. The first is to plot the distribution of the propensity scores of $\mathrm{AE}$ participants and non-participants and visually assess whether the overlap assumption holds. The second method is to compute normalized differences between the two groups (Imbens and Woolridge, 2009).

\subsection{Data and Empirical Models}

\subsubsection{Data}

The data used in this study were obtained from a household survey of a sample of 300 farm households and 576 teff plots cultivated by participants and nonparticipants of the extension program in Gozamin district, East Gojam zone, north Ethiopia. Gozamin district has high potential for cereal production due to its agroecological diversification, dependable rainfall and optimum temperature. The economy of the district is based on plough based and labour intensive agriculture, which depends mainly on meher rain (main rainy season). Main crops grown in the district in order of abundance, include teff, wheat, maize, barely, check pea, soya bean, oats, niger seed (Neug) and lentil. The district is composed of 25 kebeles of which three kebeles which represent the three main agro-ecologies (lowland, midland and 
highland) were randomly selected for the survey. Agricultural extension program participants and nonparticipants list made available by the front-line extension workers was used to select sample farmers using stratified random sampling. The data was collected during the 2011/2012 main cropping season at household and plotlevel using structured and pre-tested questionnaire by interviewing the household heads. Interviews and focus group discussions were also used to compliment the data obtained through field survey. In addition, there was no other option than to rely on the recall data for up to the last 6 months to collect the input output data, since respondents rarely had written records. However, crosschecking was done simultaneously with the help of other family members to minimize the straight forward recall error. Output and input price information was collected from nearby markets and Gozamin district marketing office. Moreover, area measurements, quantity of input and output were taken in local units and these were later converted to standard units.

\subsection{Empirical Model}

In preliminary analysis, the trans-log stochastic production function was found to be an adequate representation of the data, given the specifications of the Cobb-Douglass stochastic frontier production function. The trans-log stochastic production functional form of Equation (1) is given by:

$$
\begin{aligned}
& \ln \left(\mathrm{Y}_{\mathrm{ij}}\right)=\beta_{0}+\beta_{01}\left(\mathrm{ST}_{\mathrm{ij}}\right)+\beta_{1} \ln \left(\mathrm{LD}_{\mathrm{ij}}\right)+ \\
& \beta_{2} \ln \left(\mathrm{LR}_{\mathrm{ij}}\right)+\beta_{3} \ln \left(\mathrm{OX}_{\mathrm{ij}}\right)+\beta_{4} \ln \left(\mathrm{SC}_{\mathrm{ij}}\right)+ \\
& \beta_{5} \ln \left(\mathrm{FT}_{\mathrm{ij}}\right)+\beta_{12} \ln \left(\mathrm{LD}_{\mathrm{ij}}\right) \ln \left(\mathrm{LR}_{\mathrm{ij}}\right)+ \\
& \beta_{13} \ln \left(\mathrm{LD}_{\mathrm{ij}}\right) \ln \left(\mathrm{OX}_{\mathrm{ij}}\right)+\beta_{14} \ln \left(\mathrm{LD}_{\mathrm{ij}}\right) \ln \left(\mathrm{SC}_{\mathrm{ij}}\right)+ \\
& \beta_{15} \ln \left(\mathrm{LD}_{\mathrm{ij}}\right) \ln \left(\mathrm{FT}_{\mathrm{ij}}\right)+\beta_{23} \ln \left(\mathrm{LR}_{\mathrm{ij}}\right) \ln \left(\mathrm{OX}_{\mathrm{ij}}\right)+ \\
& \beta_{24} \ln \left(\mathrm{LR}_{\mathrm{ij}}\right) \ln \left(\mathrm{SC}_{\mathrm{ij}}\right)+\beta_{25} \ln \left(\mathrm{LR}_{\mathrm{ij}}\right) \ln \left(\mathrm{FT}_{\mathrm{ij}}\right)+ \\
& \beta_{34} \ln \left(\mathrm{OX}_{\mathrm{ij}}\right) \ln \left(\mathrm{SC}_{\mathrm{ij}} \mathrm{j}\right)+\beta_{35} \ln \left(\mathrm{OX}_{\mathrm{ij}}\right) \ln \left(\mathrm{FT}_{\mathrm{ij}}\right)+ \\
& \beta_{45} \ln \left(\mathrm{SC}_{\mathrm{ij}}\right) \ln \left(\mathrm{FT}_{\mathrm{ij}}\right)+\beta_{11} 1 / 2\left[\ln \left(\mathrm{LD}_{\mathrm{ij}}\right)\right]^{2}+ \\
& \beta_{22} 1 / 2\left[\ln \left(\mathrm{LR}_{\mathrm{ij}}\right)\right]^{2}+\beta_{33} 1 / 2\left[\ln \left(\mathrm{OX}_{\mathrm{ij}}\right)\right]^{2}+ \\
& \beta_{44} 1 / 2\left[\ln \left(\mathrm{SC}_{\mathrm{ij}}\right)\right]^{2}+\beta_{55} 1 / 2\left[\ln \left(\mathrm{FT}_{\mathrm{ij}}\right)\right]+ \\
& \mathrm{V}_{\mathrm{ij}}-\mathrm{U}_{\mathrm{ij}}
\end{aligned}
$$

Where ln denotes natural logarithm and $\mathrm{Y}_{\mathrm{ij}}$ denotes the quantity of teff yield of the ith farmer on the jth plot in kilograms per hectare; $\mathrm{ST}_{\mathrm{ij}}$ is Soil type dummy $(1=$ fertile, $0=$ otherwise), $\mathrm{LD}_{\mathrm{ij}}$ is land planted for teff production in hectares; $\mathrm{LR}_{\mathrm{ij}}$ is family and hired labor used for teff production in person day/ha; $\mathrm{OX}_{\mathrm{ij}}$ is oxen labor used for teff production in oxen day/ha; $\mathrm{SC}_{\mathrm{ij}}$ is the value of seed and agro-chemicals (pesticide, insecticide and herbicide) in Birr/ha and $\mathrm{FT}_{\mathrm{ij}}$ is chemical fertilizer used for teff production in $\mathrm{kg} / \mathrm{ha}$. The quantity of fertilizer used on some plots was zero, so we used the approach in Sherlund et al. (2002) and equated the natural logarithm of zero to the logarithm of one-tenth of the smallest non-zero value in the sample (which turned out to be 1 kilogram of fertilizer used on the plot). $\beta_{0}, \beta_{01}$ are unknown parameters to be estimated. $\mathrm{V}$ is the symmetric random variable associated with disturbances in production. $U$ is a non-negative random variable associated with technical inefficiency and is obtained by truncation (at zero) of the normal distribution with mean $\mu_{\mathrm{i}}$ and variance $\sigma_{\mathrm{u}}^{2}$, such that:

$$
\begin{aligned}
& \mu_{\mathrm{ij}}=\delta_{0}+\delta_{1} \mathrm{AGE}_{\mathrm{ij}}+\delta_{2} \mathrm{ADEQ}_{\mathrm{ij}}+\delta_{3} \mathrm{EDU}_{\mathrm{ij}}+\delta_{4} \mathrm{TLU}_{\mathrm{ij}} \\
& +\delta_{5} \mathrm{LD}_{\mathrm{ij}}+\delta_{6} \mathrm{CRD}_{\mathrm{ij}}+\delta_{7} \mathrm{AE}_{\mathrm{ij}}+\delta_{8} \mathrm{COP}_{\mathrm{ij}}+\delta_{9} \mathrm{SET}_{\mathrm{ij}}
\end{aligned}
$$

where, AGE is household head age in year; ADEQ is family size in adult equivalent scale; EDU is education status of the household head $(1=$ educated, $0=$ otherwise); TLU is livestock ownership in Tropical Livestock Unit; LD is land planted for teff production in hectare; CRD is use of credit the previous year $(1=$ yes, $0=$ no); AE represents agricultural extension program participation as dummy variable; COP is a dummy variable representing member ship in cooperatives and SET refers seed type ( $1=$ improved, $0=$ otherwise). $\delta_{\mathrm{ij}}^{\prime} \mathrm{s}$ are unknown parameters to be estimated.

It should be noted that the above model for technical inefficiencies in Equation (4) can only be estimated if the technical inefficiency effects, $U_{i}$ are stochastic and have particular distributional properties (Coelli and Battese, 1996). These conditions lead to conduct different hypothesis test using generalized likelihood-ratio statistic, $\lambda$, given by Equation (5):

$\lambda=-2\left[\ln \left\{\mathrm{L}\left(\mathrm{H}_{0}\right)\right\}-\ln \left\{\mathrm{L}\left(\mathrm{H}_{1}\right)\right\}\right]$

where, $\mathrm{L}\left(\mathrm{H}_{0}\right)$ and $\mathrm{L}\left(\mathrm{H}_{1}\right)$ denote the values of likelihood function under the null $\left(\mathrm{H}_{0}\right)$ and alternative $\left(\mathrm{H}_{1}\right)$ hypotheses, respectively. Given the specifications of the stochastic production frontier model in Equation (3) and (4), the technical efficiency index is defined as the ratio of observed output to the corresponding frontier output is given by Equation (6):

$$
\mathrm{TE}_{\mathrm{ij}}=\exp \left(-\mathrm{U}_{\mathrm{ij}}\right)
$$


The prediction of technical efficiency is based on its conditional expectations, given the model assumptions (Battese and Coelli, 1995). The parameters for the stochastic production function model in Equation (3) and those for technical inefficiency model in Equation (4) are estimated simultaneously using maximum-likelihood estimation of Frontier 4.1 program developed by Coelli (1994), which estimates the variance parameter of the likelihood function in terms of $\gamma=\frac{\sigma_{u}^{2}}{\sigma^{2}}$ and $\sigma^{2}=\sigma_{u}^{2}+\sigma_{v}^{2}$.

Unlike Cobb Douglas stochastic frontier production function the coefficients of translog production function does not have straight forward interpretation. Following Battese and Broca (1997), the elasticity of output with respect to the kth inputs are computed as:

$$
\frac{\partial \ln Y}{\partial \ln X_{k}}=\beta_{k}+\beta_{k k} \overline{\ln X_{k}}+\sum_{j=1 \neq k}^{k} \beta_{k j} \overline{\ln X_{k J}}-\theta\left(\frac{\partial \mu}{\partial X_{k}}\right)
$$

where, $\mu$ is defined by Equation (4) and $\theta$ is defined by Equation (8):

$$
\theta=1-\frac{1}{\sigma}\left\{\frac{\phi\left(\frac{\mu}{\sigma}-\sigma\right)}{\Phi\left(\frac{\mu}{\sigma}-\sigma\right)}-\frac{\phi\left(\frac{\mu}{\sigma}\right)}{\Phi\left(\frac{\mu}{\sigma}\right)}\right\}
$$

where, $\phi$ and $\Phi$ represent the density and distribution functions of the standard normal random variable, respectively. The last term in Equation (7) excluded for all variables except land as it also included in the inefficiency effects model. The elasticity of production with respect to land has two components: the first component referred to as elasticity of frontier output and the second referred to as elasticity of technical efficiency (Battese and Broca, 1997). The elasticities are evaluated at the means of the natural logarithms of the inputs.

To address selection bias in AE program participation the following logit model is estimated to obtain the propensity scores Equation (9):

$$
\operatorname{pr}(\text { AE participation }=1)=\mathrm{z}_{\mathrm{i}} \alpha+\mathrm{e}_{\mathrm{i}}
$$

where, $z_{\mathrm{i}}$ is a vector of farm and farmer characteristics (age, education, owned land size, livestock ownership, family size, oxen power, distance from extension center, involvement in kebele administration, member ship in cooperatives and location). $\alpha$ is a vector of parameters to be estimated. The propensity score of each farm is the estimated probability of being AE participant.

To address the overlap assumption the normalized difference (Imbens and Woolridge, 2009) is given by Equation (10):

$$
\Delta \mathrm{x}=\frac{\overline{\mathrm{x}}_{1}-\overline{\mathrm{x}}_{0}}{\sqrt{\sigma_{1}^{2}+\sigma_{0}^{2}}}
$$

where, $\bar{x}_{i}$ is the mean and $\sigma_{i}^{2}$ is the sample variance.

\section{RESULTS AND DISCUSSION}

\subsection{Descriptive Analysis of Unmatched Samples}

As shown in Table $\mathbf{1}$ there is significant variation between $\mathrm{AE}$ participants and non-participants in all household and farm related characteristics except age and distance from extension center. Participants have higher mean value for education, livestock ownership, land size, family size, oxenlabor, involvement in kebele administration and membership in cooperatives.

These observable characteristics are used to estimate the propensity score of unmatched samples to obtain comparable groups for frontier analysis.

\subsection{PSM Analysis}

The logit estimates of the AE participation are presented in Table 2. The logit model has a pseudo $\mathrm{R}^{2}$ value of 0.52 and correctly predicts $76 \%$ of $\mathrm{AE}$ participation. Several variables are statistically significant and associated with AE participation. As expected education increases the probability of joining the extension program. This is consistent with the notion that farmers with better human capital like education are among the early adopters (Gebregziabher et al., 2011; Giovanopoulou et al., 2011). As hypothesized, wealth indicator variables except owned land size have significant effect on the probability of participation. One more tropical livestock unit increases the probability of participation in the extension program by about $26 \%$. Family size in adult equivalent scale also increases the likelihood of participation. This is due to the labor intensive nature of Ethiopian agriculture. Hence, households who have large number of family size in adult equivalent scale have high likelihood of participation in the extension program.

Involvement in kebele administration has high coefficient value which affects the likelihood of participation. This implies that being affiliated with kebele administration, which is a non-farm related activity, increases significantly the likelihood of farmers to join the extension program. This is due to lack of clear boundary between the extension program and the political administration which often share common human and material resources. 
Table 1. Descriptive statistics of variables included in the PSM analysis

\begin{tabular}{|c|c|c|c|c|c|c|}
\hline \multirow[b]{2}{*}{ Variables } & \multirow[b]{2}{*}{ Definition } & \multicolumn{2}{|c|}{ Participants $(\mathrm{N}=364)$} & \multicolumn{2}{|c|}{ Non participants $(\mathrm{N}=214)$} & \multirow[b]{2}{*}{$\mathrm{P}$-value } \\
\hline & & Mean & S.D & Mean & S.D & \\
\hline Age & Age of the head in year & 45.520 & 10.030 & 45.450 & 9.990 & 0.937 \\
\hline Education & $\begin{array}{l}\text { Education of the head }(1 \\
=\text { educated, } 0=\text { otherwise })\end{array}$ & 0.679 & 0.468 & 0.2290 & 0.421 & 0.000 \\
\hline TLU & $\begin{array}{l}\text { Livestock ownership in } \\
\text { Tropical livestock Unit }\end{array}$ & 8.822 & 3.590 & 4.4500 & 2.180 & 0.000 \\
\hline Owned Land & Total cultivated owned land in ha & 1.532 & 0.591 & 1.0600 & 0.582 & 0.000 \\
\hline Family size & $\begin{array}{l}\text { Family size in adult } \\
\text { equivalent scale }\end{array}$ & 3.212 & 1.041 & 2.5660 & 0.956 & 0.000 \\
\hline Oxen day & $\begin{array}{l}\text { Oxen labour used for teff } \\
\text { production in oxen day/ha) }\end{array}$ & 100.330 & 51.760 & 84.810 & 37.190 & 0.000 \\
\hline pdadist & $\begin{array}{l}\text { Distance from Plot to } \\
\text { extension center(walking minute) }\end{array}$ & 38.173 & 21.970 & 40.789 & 24.090 & 0.183 \\
\hline $\begin{array}{l}\text { Kebele a } \\
\text { dminstration }\end{array}$ & $\begin{array}{l}\text { Involvement in kebele } \\
\text { administration work }\end{array}$ & 0.398 & 0.490 & 0.0140 & 0.117 & 0.000 \\
\hline Cooperatives & $\begin{array}{l}\text { Member in } \\
\text { Cooperatives }(1=\text { yes, } 0=\text { no })\end{array}$ & 0.953 & 0.211 & 0.5880 & 0.493 & 0.000 \\
\hline
\end{tabular}

Table 2. Results of logistic regression on AE participation (1/0)

\begin{tabular}{lcc}
\hline Variables & Coef. & Std. Err. \\
\hline Age (ln) & -0.587 & 0.739 \\
Education & $1.651^{* * *}$ & 0.296 \\
TLU (ln) & $2.624 * * *$ & 0.388 \\
Owned land & -0.313 & 0.299 \\
Family size & $0.309 * *$ & 0.151 \\
Oxen days (ln) & 0.735 & 0.497 \\
Plot distance from extension center & -0.154 & 0.145 \\
Kebele administration & $2.646 * * *$ & 0.685 \\
Membership in cooperatives & $2.397 * * *$ & 0.465 \\
Sitedummy_enerata (cf:Kebi) & -0.140 & 0.379 \\
Sitedummy_wonka & -0.324 & 0.323 \\
Constant & $-3.058^{* * *}$ & 3.058 \\
Observations & 576.000 & \\
Pseudo R & 0.5219 & \\
Model prediction rate: $76 \%$ & & \\
\hline
\end{tabular}

For instance, as explained in our assumption, development agents often work closely with development team who are the major components of the kebele structure established by the government. The development team has also political functions, such as mobilizing support and votes for the ruling party (Cohen and Lemma, 2011; Birhanu, 2012). Hence, it is not surprising that being in a position to involve in kebele administration increases the probability of participation in government sponsored extension program. Previous studies show that involving in local administration facilitates access to credit and fertilizer because these supplies are channeled through local agencies (Ali and Deininger, 2012; Zerfu and Larsony, 2011). Furthermore other studies show that implementation modalities are given to local agencies, so that the system is potentially open to local influence (DSA, 2006). This fact is also confirmed by (WB, 2010) report; politicians provide public services to clients in exchange for political advantage. This, in turn, leads to inequality in service provision, typically to the poor. Membership in farmers' organization has positive significance for the probability of participation in the extension program as expected and consistent with past findings (Benin et al., 2011; Abebaw and Haile, 2013).

In order to improve the robustness of the estimate the matches are restricted to $\mathrm{AE}$ participant and nonparticipant who have common support in the distribution of the propensity score. The nonparametric kernel method is used to allow matching of AE participants with the whole sample of nonparticipants, since the technique uses the whole sample of the comparison with common support to construct a weighted average match for each treated sample (Heckman et al., 1997; 1998). That is, the 
entire sample of non-participants in the comparison group is used to construct a weighted average match to each participant in the treatment group.

\subsection{Assessment on the Overlap and Unconfoundedness Assumptions}

To evaluate the overlap assumption we checked whether the balancing requirements of PSM are satisfied in our data. The balancing test in Table $\mathbf{3}$ indicates that the covariates of the two matched groups are well balanced in contrast to the unmatched samples presented in Table 1. All results of normalized differences between the two matched groups are small, suggesting that the overlap assumption is reasonable. Imbens and Wooldridge (2009) consider a normalized difference greater than 0.25 (in absolute value) to be substantial to detect any lack of overlap. Imbens and Wooldridge (2009) also argue that the assessment of the overlap assumption can be improved by graphical representation. As can be seen from Fig. 1 the distribution of propensity scores of the two groups (participant and nonparticipant) are almost identical. The graphical representation thus reinforces the results based on the normalized differences, suggesting that the overlap assumption is not a concern any more.

To evaluate the unconfoundedness assumption the placebo regression (Table 4) were employed using age of spouse of the household head as a dependent variable including AE participation and similar variables used in the estimation of the propensity scores. The dependent variable is known a priori not to be caused by $\mathrm{AE}$ participation. According to Cunguara and Darnhofer (2011), the results from these placebo regressions are not necessarily the proof that the unconfoundedness assumption holds. But non rejection of the null hypothesis that the coefficient on AE participation is zero suggests that there are no omitted variables correlated with $\mathrm{AE}$ participation. The result shows that $\mathrm{AE}$ participation does not have influence on the dependent variable, suggesting that there are no significant omitted variables. Therefore, the unconfoundedness assumption about selection on observables can be maintained and the causal interpretation of the results is plausible.

\subsection{Parametric Estimate of Stochastic Frontier Production Function}

In our preliminary analysis we estimate two different models. In the first we assume that both participants and non-participants have the same production technology. The second assumption is both groups have different production technology. Using the model that allows for different technologies (estimating a frontier with the $\mathrm{AE}$ participation dummy and the interaction terms with all the inputs), we test the null hypothesis that all these coefficients are jointly equal to zero. The result from F-stat's P-value = 0.4153 , indicates we cannot reject the null hypothesis that implies the two groups use same production technology. Hence the following frontier analysis result is based on same production technology assumption. Summary statistics of the variables used in the stochastic frontier and inefficiency model are presented in Table $\mathbf{5}$.

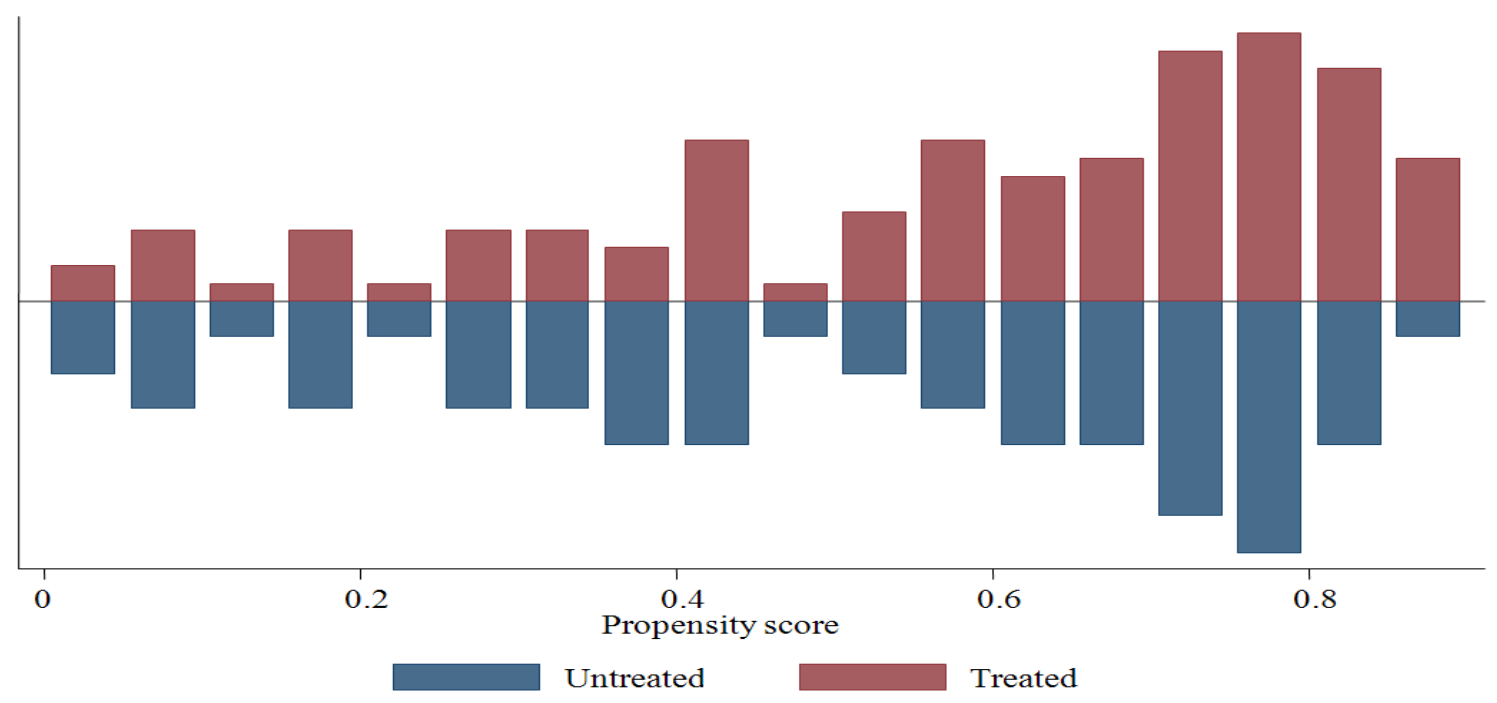

Fig. 1. Propensity score distribution of matched samples 
Asres Elias et al. / American Journal of Applied Sciences 11 (2): 223-239, 2014

Table 3. Balancing test of matched samples

\begin{tabular}{|c|c|c|c|c|c|}
\hline \multirow[b]{2}{*}{ Variable } & \multicolumn{2}{|c|}{ AE-participants $(\mathrm{N}=112)$} & \multicolumn{2}{|c|}{ Non-participants $(\mathrm{N}=56)$} & \multirow{2}{*}{$\begin{array}{l}\text { Normalized } \\
\text { difference }(\Delta x)\end{array}$} \\
\hline & Mean & Standard deviation & Mean & Standard deviation & \\
\hline$\overline{\text { Age }(\ln )}$ & 3.795 & 0.283 & 3.767 & 0.221 & 0.03 \\
\hline Education & 0.392 & 0.491 & 0.339 & 0.478 & 0.05 \\
\hline TLU (ln) & 1.766 & 0.385 & 1.699 & 0.373 & 0.07 \\
\hline Owned land & 1.323 & 0.585 & 1.258 & 0.598 & 0.05 \\
\hline Family size & 3.006 & 1.106 & 2.914 & 1.145 & 0.06 \\
\hline Oxen days $(\ln )$ & 3.164 & 0.319 & 3.119 & 0.271 & 0.05 \\
\hline $\begin{array}{l}\text { Plot distance from } \\
\text { extension center }\end{array}$ & 37.55 & 17.71 & 38.73 & 22.38 & 0.18 \\
\hline Kebele administration & 0.008 & 0.094 & 0.017 & 0.133 & -0.2 \\
\hline Membership in cooperatives & 0.928 & 0.259 & 0.857 & 0.353 & 0.09 \\
\hline Sitedummy_Enerata(cf:Kebi) & 0.241 & 0.429 & 0.232 & 0.426 & 0.01 \\
\hline Sitedummy_Wonka & 0.429 & 0.497 & 0.375 & 0.489 & 0.05 \\
\hline
\end{tabular}

Table 4. Placebo regression result

\begin{tabular}{lcc}
\hline Dependent variable: Age of head's spouse & Coefficient & P-value \\
\hline AE partcipation & 1.077 & 0.214 \\
Age of HH(ln) & 36.370 & 0.001 \\
Education of HH & 1.451 & 0.123 \\
Owned livestock(ln) & 0.394 & 0.625 \\
Owned land & -0.546 & 0.564 \\
Adult equivalent & -0.403 & 0.393 \\
Oxen days (ln) & 0.012 & 0.979 \\
Plot distance from extension center(ln) & -0.473 & 0.256 \\
Kebele administration & -0.161 & 0.930 \\
Membership in cooperatives & -1.418 & 0.419 \\
Sitedummy_enerata (cf:Kebi) & 1.789 & 0.008 \\
Sitedummy_wonka & 1.602 & 0.009 \\
constant & -99.520 & 0.003 \\
Number of observations & 168.000 & \\
F(10, 156) & 142.870 & 0.000 \\
Prob > F & 0.760 & \\
R squared & &
\end{tabular}

Table 5. Summary statistics of variables included in the efficiency analysis for matched samples

\begin{tabular}{|c|c|c|c|c|c|}
\hline \multirow[b]{2}{*}{ Variables } & \multirow[b]{2}{*}{ Definition } & \multicolumn{2}{|c|}{ Participants $(\mathrm{N}=112)$} & \multicolumn{2}{|c|}{ Non-participants $(\mathrm{N}=56)$} \\
\hline & & Mean & S.D & Mean & S.D \\
\hline $\begin{array}{l}\text { Dependent } \\
\text { variable: Yield } \\
\text { Input variables: }\end{array}$ & teff yield in $\mathrm{kg} / \mathrm{ha}$ & 1558.900 & 568.000 & 1285.600 & 358.000 \\
\hline Soil type & $1=$ fertile, $0=$ otherwise & 0.250 & 0.434 & 0.230 & 0.426 \\
\hline Land & land planted to teff production in ha & 0.299 & 0.166 & 0.333 & 0.159 \\
\hline Labour & labour used in person day/ha & 125.600 & 69.860 & 106.400 & 33.370 \\
\hline Oxen day & oxen labour used in oxen day/ha & 100.100 & 53.840 & 80.190 & 28.880 \\
\hline $\begin{array}{l}\text { Seed and agro- } \\
\text { Chemicals }\end{array}$ & $\begin{array}{l}\text { seed and agro-chemicals } \\
\text { (pesticide and herbicide) cost in birr/ha }\end{array}$ & 355.200 & 112.100 & 327.100 & 91.290 \\
\hline $\begin{array}{l}\text { Fertilizer } \\
\text { Farm specific variables }\end{array}$ & chemical fertilizer used in $\mathrm{kg} / \mathrm{ha}$ & 140.000 & 93.950 & 85.510 & 43.440 \\
\hline Age & Age of the head in year & 46.240 & 12.680 & 45.270 & 10.510 \\
\hline Family size & Family size in adult equivalent scale & 3.001 & 1.105 & 2.915 & 1.144 \\
\hline Education & $\begin{array}{l}\text { Education of the head } \\
\text { ( } 1=\text { educated, } 0=\text { otherwise })\end{array}$ & 0.392 & 0.491 & 0.339 & 0.478 \\
\hline TLU & Livestock ownership in tropical livestock Unit & 6.279 & 2.417 & 5.867 & 2.364 \\
\hline Plot size & Land planted to teff production in ha & 0.299 & 0.165 & 0.333 & 0.159 \\
\hline Credit & Use of credit previous year $(1=$ yes, $0=$ no $)$ & 0.232 & 0.426 & 0.196 & 0.399 \\
\hline AE participation & $1=$ participant $0=$ non-participant & 1.000 & 0.000 & 0.000 & 0.000 \\
\hline Cooperatives & Member in cooperatives $(1=$ yes, $0=$ no $)$ & 0.928 & 0.259 & 0.857 & 0.353 \\
\hline Seed type & $1=$ improved seed, $0=$ local seed & 0.205 & 0.405 & 0.136 & 0.277 \\
\hline
\end{tabular}


The maximum-likelihood estimates of the parameters of the translog stochastic frontier and inefficiency models based on PSM subsample are presented in Table 6. The functional specification is tested first. The choice of the empirical frontier production function was made based on the generalized likelihood ratio test (Coelli and Battese, 1996). The null hypothesis that the CobbDouglas model is appropriate representation of the data was strongly rejected (Table 7). Therefore, the trans-log stochastic frontier and inefficiency model is more suitable to the farm survey data that adequately captures the production behavior of teff producer farmers in the study area. As expected, the frontier output elasticities of land, labor, oxen, seed and agrochemicals and fertilizer, are positive and significant. The dummy variable soil type has also positive and significant effect on teff production.

Table 6. Maximum likelihood estimates of the translog stochastic frontier and inefficiency model

\begin{tabular}{|c|c|c|c|c|c|}
\hline Variables & Parameters & ML estimate & t-value & Elasticity of output & t-value \\
\hline \multicolumn{6}{|l|}{ Stochastic frontier } \\
\hline Constant & $\beta_{0}$ & 26.598 & $3.170 * * *$ & & \\
\hline Soil type (dummy) & $\beta_{01}$ & 0.199 & $4.226 * * *$ & & \\
\hline $\ln ($ Land $)$ & $\beta_{1}$ & -4.102 & $-2.025 * *$ & 0.144 & $2.115 * *$ \\
\hline $\ln ($ Labour $)$ & $\beta_{2}$ & -1.795 & -0.628 & 0.236 & $1.99 *$ \\
\hline $\ln ($ Oxen day $)$ & $\beta_{3}$ & -2.101 & -0.723 & 0.343 & $3.190 * * *$ \\
\hline $\ln ($ Seed and agro-chemicals) & $\beta_{4}$ & -5.421 & $-2.366^{* *}$ & 0.122 & $1.853 *$ \\
\hline $\ln$ (Fertilizer) & $\beta_{5}$ & 0.621 & 1.451 & 0.066 & $3.621 * * *$ \\
\hline $\ln ($ Land $) x \ln ($ Labour $)$ & $\beta_{12}$ & 0.709 & $2.175 * *$ & & \\
\hline $\ln ($ Land $) x \ln ($ Oxen day $)$ & $\beta_{13}$ & -0.096 & -0.297 & & \\
\hline $\ln ($ Land $) x \ln ($ Seed and agro-chemicals $)$ & $\beta_{14}$ & 0.380 & 1.319 & & \\
\hline $\ln ($ Land $) x \ln ($ Fertilizer $)$ & $\beta_{15}$ & -0.101 & -0.996 & & \\
\hline $\ln ($ Labour)x $\ln ($ Oxen day) & $\beta_{23}$ & 0.043 & -0.076 & & \\
\hline $\ln ($ Labour $) x \ln ($ Seed and agro-chemicals $)$ & $\beta_{24}$ & 0.222 & 0.488 & & \\
\hline $\ln ($ Labour $) x \ln ($ Fertilizer $)$ & $\beta_{25}$ & -0.127 & -1.553 & & \\
\hline $\ln ($ Oxen day)x $\ln$ (Seed and agro-chemicals) & $\beta_{34}$ & 0.523 & 1.113 & & \\
\hline $\ln ($ Oxen day $) x \ln ($ Fertilizer $)$ & $\beta_{35}$ & -0.087 & -0.917 & & \\
\hline $\ln ($ Seed and agro-chemicals)x $\ln$ (Fertilizer) & $\beta_{45}$ & -0.004 & -0.043 & & \\
\hline $\ln ($ Land $) x \ln ($ Land $)$ & $\beta_{11}$ & 0.161 & 0.949 & & \\
\hline $\ln ($ Labour $) x \ln ($ Labour $)$ & $\beta_{22}$ & 0.203 & 0.609 & & \\
\hline $\ln ($ Oxen day $) x \ln ($ Oxen day $)$ & $\beta_{33}$ & -0.056 & -0.209 & & \\
\hline $\ln ($ Seed and agro-chemicals $) \mathrm{x}$ & $\beta_{44}$ & 0.220 & 1.171 & & \\
\hline \multicolumn{6}{|l|}{$\ln$ (Seed and agro-chemicals) } \\
\hline ln (Fertilizer)x ln (Fertilizer) & $\beta_{55}$ & 0.053 & $4.927 * * *$ & & \\
\hline \multicolumn{6}{|l|}{ Inefficiency model } \\
\hline Constant & $\delta_{0}$ & 0.464 & $2.299 * *$ & & \\
\hline Age & $\delta_{1}$ & 0.004 & 1.214 & & \\
\hline Family size & $\delta_{2}$ & 0.032 & 1.097 & & \\
\hline Education & $\delta_{3}$ & -0.088 & -1.018 & & \\
\hline TLU & $\delta_{4}$ & -0.039 & $-2.519 * *$ & & \\
\hline Plot size & $\delta_{5}$ & -0.419 & -1.081 & & \\
\hline Credit & $\delta_{6}$ & -0.242 & $-2.535^{* *}$ & & \\
\hline AE participation & $\delta_{8}$ & -0.048 & -0.708 & & \\
\hline Membership in cooperatives & $\delta_{9}$ & -0.011 & -0.103 & & \\
\hline Seed type & $\delta_{10}$ & -0.239 & $-1.98 *$ & & \\
\hline \multicolumn{6}{|l|}{ Variance parameters } \\
\hline Sigma-square & $\sigma^{2}$ & 0.063 & $4.266^{* * *}$ & & \\
\hline Gamma & $\gamma$ & 0.881 & $8.715^{* * *}$ & & \\
\hline Ln likelihood & 27.896 & & & & \\
\hline
\end{tabular}


Asres Elias et al. / American Journal of Applied Sciences 11 (2): 223-239, 2014

Table 7. Generalized Likelihood Ratio (LR) tests of hypotheses involving the parameters of the stochastic frontier and inefficiency model

\begin{tabular}{llrl}
\hline Null hypothesis & LR statistics $(\lambda)$ & Critical value $\left(\mathrm{x}^{2}\right)$ & Decision \\
\hline $\mathrm{H}_{0}: \beta_{\mathrm{k}, \mathrm{j}}=0$ (Cobb-douglas) & 53.64 & 24.99 & Reject $\mathrm{H}_{0}$ \\
$\mathrm{H}_{0}: \gamma=0$ (tradional production function) & 40.79 & 2.71 & Reject $\mathrm{H}_{0}$ \\
$\mathrm{H}_{0}: \delta_{1}=\delta_{2}=\delta_{10}=0$ & 31.09 & 18.31 & Reject $\mathrm{H}_{0}$ \\
\hline
\end{tabular}

\subsection{Factors Influencing Technical Efficiency}

The estimated coefficients of the explanatory variables in the model for technical inefficiency effects are of particular interest of this study and have important implications. The values for the parameters $\sigma^{2}$ and $\gamma$ are reported at the end of Table 6. The parameter $\gamma$ is statistically significant at the $1 \%$ level, with an estimated value of 0.88 . These results indicate that inefficiency is highly significant among the studied farms. On top of that, the value of gamma $(\gamma)$ indicates that there is $88 \%$ variation in output due to technical inefficiency. Furthermore, the null hypothesis $\mathrm{H}_{0}: \gamma=0$, tests whether the traditional average production function is appropriate as opposed to a frontier production function. As shown in Table $\mathbf{7}$, the test result revealed that the traditional response function is not an adequate representation of teff production in the study area, given the specifications of the translog stochastic frontier and inefficiency model. In other words, the result confirms that inefficiency exist and is indeed stochastic. The hypothesis that the explanatory variables in the model for the technical inefficiency effects have zero coefficients $\mathrm{H}_{0}=\delta_{1}=\delta_{2}$ $==\delta_{10}=0$ is rejected. This implies that joint estimation of the explanatory variables have a significant impact on technical efficiency.

Since the dependent variable of the inefficiency model, Equation 4, is defined in terms of technical inefficiency, a farm-specific variable associated with the negative (positive) coefficient will have a positive (negative) impact on technical efficiency. The results of the study in Table 6 indicate that, livestock ownership (TLU), credit and seed type are significant factors and have positive impact on technical efficiency (negative impact on technical inefficiency), while age of the head, family size, education, plot size, AE participation and member ship in cooperatives do not have significant effect in reducing technical inefficiency.

The variable livestock ownership (TLU) has a positive and significant effect on technical efficiency in teff production. Livestock holding is a proxy for liquidity or access to cash. It is obvious that the crop husbandry is highly supplemented and complemented by the animal husbandry. It has systematic effect on efficiency i.e., the farmer who possesses more number of livestock will have more money to purchase agricultural inputs and again used for draft power especially teff production in Ethiopia needs intensive draft power from land preparation to post harvest and timely transportation of the yield. The result is in agreement with (Ahmed et al., 2002; Alene and Manyong, 2006; Alemu et al., 2009) who found a positive and significant effect of livestock ownership on technical efficiency.

Credit has a significant inefficiency reducing effect on technical efficiency. This implies that access to credit in cash and/or in kind is likely to enhance the technical efficiency of teff producer farmers in the study area through the alleviation of capital constraints and thus enables farmers to make timely purchases of inputs that they cannot afford from their own resources. In the study area, credit is used for purchase of oxen and agricultural inputs. Our result is in agreement with Binam et al. (2004); Alene and Hassan (2008) and Assefa (2011); who found the inefficiency reducing effect of credit on technical efficiency.

Use of improved seed has a significant inefficiency reducing effect. Farms with improved seed are more efficient than farms using local seeds. The popular teff variety in general in Ethiopia and particularly in the study area is called Quncho. According to Assefa et al. (2011b) and Fufa et al. (2011) Quncho was developed from an intra-specific hybridization between two improved pure line selection varieties (DZ-01-974 and DZ-01-196). However, the role of improved teff seed is not over emphasized due to short comings in seed quality and timeliness of delivery that have been long standing issues in Ethiopia. According to DSA (2006) poor cleaning, broken seed, low germination rates and the presence of mixed seeds have been reported in supplied seeds. This fact is also confirmed during our focus group discussion with farmers and extension workers.

Although insignificant, the influence of $\mathrm{AE}$ participation which is the main point of this study on technical efficiency tends to be positive. The insignificant positive effect of $\mathrm{AE}$ participation on technical efficiency might be due to poor performance in the operation of extension systems, deficient program design and information delivery systems. 
Asres Elias et al. / American Journal of Applied Sciences 11 (2): 223-239, 2014

Table 8. Technical efficiency distribution of AE participant and non-participant teff producer farms

\begin{tabular}{|c|c|c|c|c|c|c|}
\hline \multirow[b]{2}{*}{ Efficiency score } & \multicolumn{2}{|c|}{ AE participants } & \multicolumn{2}{|c|}{ Non-participants } & \multicolumn{2}{|l|}{ All } \\
\hline & Number & Percent & Number & Percent & Number & Percent \\
\hline $\begin{array}{l}<50 \\
\end{array}$ & 8.00 & 7.14 & 5.00 & 8.93 & 13.00 & 7.74 \\
\hline $51-60$ & 17.00 & 15.18 & 9.00 & 16.08 & 26.00 & 15.48 \\
\hline $61-70$ & 28.00 & 25.00 & 11.00 & 19.64 & 39.00 & 23.21 \\
\hline $71-80$ & 20.00 & 17.86 & 14.00 & 25.00 & 34.00 & 20.23 \\
\hline $81-90$ & 24.00 & 21.43 & 13.00 & 23.21 & 37.00 & 22.02 \\
\hline $91-100$ & 15.00 & 13.39 & 5.00 & 8.93 & 20.00 & 11.91 \\
\hline Mean & 72.29 & & 71.44 & & 72.00 & \\
\hline Minimum & 33.09 & & 35.01 & & 33.09 & \\
\hline Maximum & 95.98 & & 95.87 & & 95.98 & \\
\hline
\end{tabular}

Our field investigation and review of past researches (Abate, 2007; Kassa, 2008) show that the extension implementation in Ethiopia is constrained by a number of factors such as supply-push rather than demand-pull approach, poorly organized technology multiplication system, absence of institutional pluralism, low technology adoption rate, shortage of basic training for extension staff and mainly the tendency of many extension stakeholders dealing with the transmission of knowledge to conduct their assignment in a top-down manner. Often, the information conveyed is presented as a technological package comprising recommended practices. This is perceived as a less effective method for improving knowledge and skill. In this case, more participatory approaches are suggested to extend science-based knowledge and practices (Braun et al., 2002). The empirical evidence regarding the influence of the Ethiopian agricultural extension service on technical efficiency is mixed. For instance, (Seyoum et al., 1998; Khairo and Battese, 2005) found a positive significant effect. On the other hand other studies conducted in Ethiopia by (Alene and Hassan, 2008; Alemu et al., 2009) reported that agricultural extension participation has no effect on technical efficiency.

\subsection{Technical Efficiency Distribution}

Frequency distributions of the TE estimates are presented in Table 8. Estimated TE scores revealed that nearly $22 \%$ of the farms achieved efficiency from 81 to $90 \%$, nearly $11 \%$ from 91 to $100 \%$ and the rest below these ranges with the mean efficiency of all the farms about $72 \%$. This means that farms are performing on average $28 \%$ below their potential level. With little changes in the production process like better use and allocation of resources, farm management practices and efficient farming decisions, TE and hence the production level of the farms could be increased by around $28 \%$. Since most of the farms are operating below the frontier level there is ample space for teff output growth through full improvements in TE.

On the other hand, the mean TE estimates for AE participant and non-participant teff producer farms are almost similar. AE participant farms have an average TE of $72.29 \%$, the corresponding measure for nonparticipants is $71.44 \%$. The participants and nonparticipants can gain, respectively, an average teff output growth of 27.71 and $28.56 \%$ through full improvements in TE. Most $(25 \%)$ of $\mathrm{AE}$ participant farms have TE score between 61 to $70 \%$ whereas $25 \%$ of nonparticipant farms have TE ranging between 71 to $80 \%$.

\section{CONCLUSION}

This study employed propensity score matching technique that accounts for endogenity of agricultural extension participation to estimate technical efficiency of two types of farmers, participants and non-participants of agricultural extension program in Gozamin district, North Ethiopia. Since Teff is the main staple food in Ethiopia, high productivity and efficiency in its production are crucial to food security in the country. However, teff production under improved technology encounters substantial inefficiencies.

The econometric results based on the stochastic production function indicate that the mean technical efficiency estimates for AE participant and nonparticipant teff producer farms are almost similar i.e., 72.29 and $71.44 \%$ respectively. Therefore, AE participation has had no positive significant influence on technical efficiency of teff producer farms. Moreover, both groups of farms have considerable overall technical inefficiencies suggesting the existence of immense potentials for enhancing production through improvements in efficiency with available technology and resources. An investigation of the influence of household and farm specific factors on efficiency revealed that livestock 
ownership (TLU), credit and improved seed are positively influence technical efficiency.

Despite the long history of government investment in the agricultural sector through extension service and promotion of new technology, smallholders'teff production remains technically inefficient. Therefore, based on the results of this study the following points are suggested to enhance teff production via improvement in efficiency. First there is a need for providing extension services with respect to technical skill and farm management capacity of the farmers. Besides demand driven livestock extension service are needed to enhance the complementary role of livestock production in minimizing liquidity constraints of farmers. Second greater access to credit service for farmers are needed to enhance their financial capacity which leads them to adopt improved technologies as well as practices that will ultimately increase their efficiency in farm production. Third, increasing the availability, quality and adoption of improved seed is required.

We acknowledge, however, that our results cannot be generalized at the national level since the sample was not representative of the entire country. Hence to get more representative figure about the role of the extension program on farm technical efficiency at national level, conducting similar studies further dealing with a wider sample size coverage and time series data that considers other types of crops is important.

\section{REFERENCES}

Abate, H., 2007. Review of extension systems applied in Ethiopia with special emphasis to the participatory demonstration and training extension system. Agriculture Organization of the United Nations.

Abate, T., B. Shiferaw, S. Gebeyehu, B. Amsalu and K. Negash et al., 2011. A systems and partnership approach to agricultural research for development: Lessons from Ethiopia. Outlook Agric. J., 40: 213220. DOI: $10.5367 /$ oa.2011.0048

Abebaw, D. and M.G. Haile, 2013. The impact of cooperatives on agricultural technology adoption: Empirical evidence from Ethiopia. Food Policy, 38: 82-91. DOI: 10.1016/j.foodpol.2012.10.003

Ahmed, M.M., B. Gebremedhin, S. Benin and S. Ehui, 2002. Measurement and source of technical efficiency of land tenure contracts in Ethiopia. Environ. Dev. Econ., 7: 507-528. DOI: 10.1017/S1355770X0200030X
Aigner, D.J., C.K. Lovell and P. Schmidt, 1977. Formulation and estimation of stochastic frontier production function models. J. Econ., 6: 21-37. DOI: 10.1016/0304-4076(77)90052-5

Alemu, B.A., E.A. Nuppenau and H. Boland, 2009. Technical efficiency of farming systems across agro-ecological zones in Ethiopia: An application of stochastic frontier analysis. Agric. J., 4: 202207.

Alene, A.D. and M. Zeller, 2005. Technology adoption and farmer efficiency in multiple crops production in eastern Ethiopia: A comparison of parametric and non-parametric distance functions. Agric. Econ. Rev., 6: 5-17.

Alene, A.D. and R.M. Hassan, 2006. The efficiency of traditional and hybrid maize production in Eastern Ethiopia: An extended efficiency decomposition approach. J. Afr. Econ., 15: 91-116. DOI: 10.1093/jae/eji017

Alene, A.D. and R.M. Hassan, 2008. Efficiency of food production under old and new technology: The case of farmers within and outside the extension package program in Ethiopia. J. Dev. Areas, 41: 233-249. DOI: $10.1353 /$ jda.2008.0010

Alene, A.D. and V.M. Manyong, 2006. Farmer to farmer technology diffusion and yield variation among adopters: The case of improved cowpea in northern Nigeria. Agric. Econ., 35: 203-211. DOI: 10.1111/j.1574-0862.2006.00153.x

Ali, D.A. and K. Deininger, 2012. Causes and Implications of Credit Rationing in Rural Ethiopia: The Importance of Spatial Variation. 1st Edn., World Bank, Washington, D.C., pp: 27.

Asfaw, S., B. Shiferaw, F. Simtowe and L. Lipper, 2012. Impact of modern agricultural technologies on smallholder welfare: Evidence from Tanzania and Ethiopia. Food Policy, 37: 283-295. DOI: 10.1016/j.foodpol.2012.02.013

Assefa, K., J.K. Yu, M. Zeid, G. Belay and H. Tefera et al., 2011a. Breeding tef [Eragrostis tef (Zucc.) trotter]: conventional and molecular approaches (review). Plant Breed., 130: 1-9. DOI: 10.1111/j.14390523.2010.01782.x

Assefa, K., S. Aliye, G. Belay, G. Metaferia and H. Tefera et al., 2011b. Quncho: The first popular tef variety in Ethiopia. Int. J. Agric. Sustain., 25-34. DOI: 10.3763 ijas.2010.0545

Assefa, S., 2011. Analysis of technical efficiency of crop producing smallholder farmers in Tigray, Ethiopia. Munich Personal RePEc Archive. 
ATA, 2012. Strengthening the tef value chain in ethiopia. Ethiopian Agricultural Transformation Agency.

Ayele, G., M. Bekele and S. Zekeria, 2006. Productivity and efficiency of agricultural extension package in Ethiopia. Ethiopian Development Research Institute.

Barrett, C., T. Reardon and P. Webb, 2001. Nonfarm income diversification and household livelihood strategies in rural Africa: Concepts, dynamics and policy implications. Food Policy, 26: 315-31. DOI: 10.1016/S0306-9192(01)00014-8

Battese, G. and S. Broca, 1997. Functional forms of stochastic frontier production functions and models for technical inefficiency effects: A comparative study for wheat farmers in Pakistan. J. Prod. Anal., 8: 395-414. DOI: 10.1023/A: 1007736025686

Battese, G.E. T.J. Coelli and T.C. Colby, 1989. Estimation of frontier production functions and the efficiencies of Indian farms using panel data from ICRISAT's village level studies. J. Quant Econ., 5: 327-348.

Battese.G.E. and T.J. Coelli, 1995. A model of technical inefficiency effects in a stochastic frontier production function for panel data. Empir. Econ., 20: 325-332. DOI: 10.1007/BF01205442

Benin, S., E. Nkonya, G. Okecho, J. Randriamamonjy and E. Kato et al., 2011. Returns to spending on agricultural extension: The case of the National Agricultural Advisory Services (NAADA) Program of Uganda. Agric. Econ., 42: 249-267. DOI: 10.1111/j.1574-0862.2010.00512.x

Binam, J.N., J. Tonye, N. Wandji, G. Nyambi and M. Akoa, 2004. Factors affecting the technical efficiency among smallholder farmers in the slash and burn agriculture zone of Cameroon. Food Policy, 29: 531-545. DOI: 10.1016/j.foodpol.2004.07.013

Birhanu, K., 2012. The political economy of agricultural extension in ethiopia: Economic Growth and Political Control, Siani.

Braun, A., G. Thiele and M. Fernandez, 2002. Farmer field schools and local agricultural research committee: Complementary platforms for integrated decision-making in sustainable agriculture. ODI, Agricultural Research and Extension Network, pp: 105 .
Bravo-Ureta, B.E. and A.E. Pinheiro, 1997. Technical, economic and allocative efficiency in peasant farming: Evidence from the dominican republic. Dev. Econ., 35: 48-67. DOI: 10.1111/j.1746-1049.1997.tb01186.x

Caliendo, M. and S. Kopeinig, 2008. Some practical guidance for the implementation of propensity score matching. J. Econ. Surveys, 22: 31-72. DOI: 10.1111/j.1467-6419.2007.00527

Coelli, T.J. and G.E. Battese, 1996. Identification of factors which influence the technical efficiency of Indian farmers. Aust. J. Agric. Econ., 40: 103-128. DOI: $10.1111 /$ j.1467-8489.1996.tb00558.x

Coelli, T.J., 1994. A guide to FRONTIER version 4.1: Acomputer program for stochastic frontier production and cost function estimation. Mimeo, Department of Econometrics, University of New England, Armidale, Australia.

Coelli, T.J., D.S. PrasadaRao, C.J. O’Donnell and G.E. Battese, 2005. An Introduction to Efficiency and Productivity Analysis. 2nd Edn., Springer, New York, ISBN-10: 0387242651, pp: 349.

Coelli,T.J., 1996. Aguide to Frontier Version 4.1: Acomputer program for frontier production function estimation. CEPA Working, Department of Econometrics, University of New England, Armidale.

Cohen, M.J. and M. Lemma, 2011. Agricultural extension services and gender equality: An institutional analysis of four districts in Ethiopia. IFPRI Discussion Paper 01094.

CSA, 2008. Central Statistical Agency. Ethiopia, Addis Ababa.

Cunguara, B. and I. Darnhofer, 2011. Assessing the impact of improved agricultural technologies on household income in rural Mozambique. Food Policy, 36: 378-390. DOI: 10.1016/j.foodpol.2011.03.002

Cunguara, B. and K. Moder, 2011. Is agricultural extension helping the poor? Evidence from rural Mozambique. J. Afr. Econ., 20: 562-595. DOI: 10.1093/jae/ejr015

Dehejia, R. and S. Wahba, 2002. Propensity score matching methods for non-experimental causal studies. Rev. Econ. Statist., 84: 151-161. DOI: 10.1162/003465302317331982

Dey, M.M., F.J. Paraguas, N. Sricantuk, Y. Xinhua and R. Bhatta et al., 2005. Technical efficiency of freshwater pond polyculture production in selected asian countries: Estimation and implication. Aquac. Econ. Manage., 9: 39-63. DOI: $10.1080 / 13657300590961528$ 
Doss, C.R. and M.L. Morris, 2000. How does gender affect the adoption of agricultural innovations? Agric. Econ., 25: 27-39. DOI: 10.1111/j.15740862.2001.tb00233.x

DSA, 2006. Study on improving the efficiency of input markets. Ministry of Agriculture and Rural Development, Ethiopia, Addis Ababa.

EEA/EEPRI, 2006. Evaluation of the Ethiopian Agricultural Extension with Particular Emphasis on the Participatory Demonstration and Training Extension System (PADETES). 1st Edn., Addis Ababa, Ethiopia

FAO, 2010. Ethiopia Country Brief.

Farrell, M.J., 1957. The measurement of production efficiency. J. Royal Statist. Soc., 120: 253-282. DOI: $10.2307 / 2343100$

Fufa, B., B. Behute, R. Simons and T. Berhe, 2011. Strengthening the teff value chain in Ethiopia. Mimeo, Agricultural Transformation Agency (ATA), Addis Ababa.

Gebregziabher, K.G., E. Mathijs, M. Maertens, J. Deckers and H. Bauer, 2011. Extension participation, household income and income diversification: A System Equations Approach.

Gebremedhin, B., M. Jalata and D. Hoekstra, 2009. Smallholders, institutional services and commercial transformation in Ethiopia. Agric. Econ., 40: 773787. DOI: 10.1111/j.1574-0862.2009.00414

Giovanopoulou, E., S.A. Nastis and E. Papanagiotou, 2011. Modeling farmer participation in agrienvironmental nitrate pollution reducing schemes. Ecological Econ., 7: 2175-2180. DOI: 10.1016/j.ecolecon.2011.06.022

Heckman, J., H. Ichimura J. Smith and P. Todd, 1998. Characterizing selection bias using experimental data. Econometrica, 66: 1017-1098. DOI: $10.2307 / 2999630$

Heckman, J., H. Ichimura, J. Smith and P. Todd, 1997. Matching as econometric evaluation estimator: Evidence from evaluating a job-training program. Rev. Econ. Stud., 64: 605-654. DOI: 10.1111/1467937X.00044

Heckman, J.J. and S. Navarro-Lozano, 2004. Using matching, instrumental variables and control functions to estimate economic choice models. Rev. Econ. Statist., 86: 30-57. DOI: 10.1162/003465304323023660

Imbens, G.M. and J.M. Wooldridge, 2009. Recent developments in the econometrics of program evaluation. J. Econ. Literat., 47: 5-86. DOI: $10.1257 /$ jel.47.1.5
Kassa, B. and D. Abebaw, 2004. Challenges facing agricultural extension agents: A case study from South-Western Ethiopia. African Dev. Rev., 16: 139-168. DOI: 10.1111/j.1467-8268.2004.00087

Kassa, B., 2003. Agricultural extension in Ethiopia: The case of participatory demonstration and training extension system. J. Soc. Dev. Afr., 18: 49-83.

Kassa, H., 2008. Agricultural extension in Ethiopia: Historical Evolution, Relevant Policies and Challenges. In: Digest of Ethiopia's National Policies, Strategies and Programs, Assefa, T. (Ed.), African Books Collective, Addis Ababa, ISBN-10: 9994450190.

Kassie, M., P. Zikhali, K. Manjur and E. Edward, 2009. Adoption of sustainable agriculture practices: Evidence from a semi-arid region of Ethiopia. Natural Resources Forum, 39: 189-198. DOI: 10.1111/j.1477-8947.2009.01224

Khairo, S.A. and G.E. Battese, 2005. A study of technical inefficiencies of maize farmers within and outside the new agricultural extension program in the Harari region of Ethiopia. South African J. Agric. Extension, 34: 136-150.

Mayen, C.D., J.V. Balagtas and C.E. Alexander, 2010. Technology adoption and technical efficiency: Organic and conventional dairy farms in the United States. Am. J. Agric. Econ., 92: 181-195. DOI: 10.1093/ajae/aap018

Meeusen, W. and J.V. den Broeck, 1977. Efficiency estimation from Cobb-Douglas production functions with composed error. Int. Econ. Rev., 18: 435-444. DOI: $10.2307 / 2525757$

Nkamleu, G.B., 2004. Productivity growth, technical progress and efficiency change in African agriculture. Afr. Dev. Rev., 16: 203-222. DOI: 10.1111/j.1467-8268.2004.00089.x

Nyemeck, B.J., K. Sylla, I. Diarra and G. Nyambi, 2003. Factors affecting technical efficiency among coffee farmers in Côte d'Ivoire: Evidence from the centre west region. African Dev. Rev., 15: 66-76. DOI: 10.1111/1467-8268.00063

Pender, J. and B. Gebremedhin, 2007. Determinants of agricultural and land management practices and impacts on crop production and household income in the highlands of Tigray, Ethiopia. J. African Econ., 17: 395-450. DOI: 10.1093/jae/ejm028 
Rao, E.J.O., B. Brummer and M. Qaim, 2012. Farmer participation in supermarket channels, production technology and efficiency: The case of vegetables in Kenya. Am. J. Agr. Econ., 94: 891-912. DOI: 10.1093/ajae/aas024

Reifschneider, D. and R. Stevenson, 1991. Systematic departures from the frontier: A framework for the analysis of firm inefficiency. Int. Econ. Rev., 32: 715-723. DOI: $10.2307 / 2527115$

Rubin, D.B., 1977. Assignment to treatment group on the basis of a covariate. J. Educ. Stat., 2: 1-26. DOI: 10.3102/10769986002001001

Seyoum, E.T., G.E. Battese and E.M. Fleming, 1998. Technical efficiency and productivity of maize producers in eastern Ethiopia: A study of farmers within and outside the Sasakawa-Global 2000 project. Agric. Econ., 341-348. DOI: 10.1016/S0169-5150(98)00037-1

Sherlund, S.M., C.B. Barrett and A.A. Adesina, 2002. Smallholder technical efficiency controlling for environmental production conditions. J. Dev. Econ., 69: 85-101. DOI: 10.1016/S0304-3878(02)00054-8
Smith, J. and P. Todd, 2005. Does matching overcome Lalonde's Critique of non-experimental estimators. J. Econometrics, 125: 305-353. DOI: 10.1016/j.jeconom.2004.04.011

Solis, D., B.E. Bravo-Ureta and R.E. Quiroga, 2007. Soil conservation and technical efficiency among hillside farmers in Central America: A switching regression model. Australian J. Agric. Res. Econ., 51: 491-510. DOI: 10.1111/j.1467-8489.2007.00394.x

Thangata, P. and T. Mequaninte, 2011. The impact of agricultural extension services on farm household efficiency in Ethiopia.

WB, 2010. Agriculture and rural development series: Gender and governance in rural Service: Insight from India, Ghana and Ethiopia, World Bank, Washington, D.C.

Zerfu, D. and D.F. Larsony, 2011. Incomplete markets and fertilizer use: Evidence from Ethiopia. 